\title{
LAW ENFORCEMENT OF ELECTRICAL AND ELECTRONIC WASTE SMUGGLING IN BATAM, INDONESIA
}

\author{
FX.Joko Priyono \\ Faculty of Law, Diponegoro University Semarang \\ fransiskusjoko893@gmail.com
}

\begin{abstract}
Electrical and electronic waste (e-waste) are dangerous for human health and environment. The e-waste may comes from both external (import) and domestic industries. Batam as part of Indonesia jurisdiction have been a place of e-waste dumping. The e-waste mostly comes from Singapore. The rest is from Malaysia, Thailand, and Vietnam. The influx of electronic waste is done through smuggling at certain place. Police actually knows about the smuggling but not take any action. This crimes was backed up by any army and police. It reflects the ineffectiveness of law enforcement in Batam regarding e-waste smuggling. The ignorance causes the environment and human health is not well protected. Lack of understanding of legal knowledge by law enforcement agencies should be a particular concern for the government. On the other hand, for the people of Batam, e-waste still have economic value. Therefore, they don't care about the menace of e-waste to human health and environment. The government should develop them in order to manage $e$-waste properly. The government may refer to the Government of India's Bangalore city with regard to how the people manage e-waste.
\end{abstract}

Keywords: Law Enforcement, E-Waste Smuggling, Batam

\section{Introduction}

Electrical and electronic waste, or called e-waste, is a term used to cover items of all types of electrical and electronic equipment (EEE) and its parts that have been discarded by the owner as waste without the intention of re-use. ${ }^{1}$ The use of the term "discarded" is also central to this definition, meaning to throw away or get rid of as useless. The term implies that the item in question is considered excess or waste by the owner. It is the critical point at which the potential nature of the

\footnotetext{
${ }^{1}$ Step (Solving the E-waste Problem), 2014. One Global Definition of E-Waste, United Nations University, 3 june 2014, page 5.
}

Diponegoro Law Review, April 2017, Volume 02, Number 01 
item changes from a useful product to that of waste. E-waste comprises refrigerators, washing machines, and microwaves, TVs, Radio and computers, mobile phones, printers, air conditioners that have reached their ends for their current holder. ${ }^{2}$ There is no generally accepted definition of e-waste around the world. Used electronics which are destined for reuse, resale, salvage, recycling, or disposal are also considered e-waste. Informal processing of e-waste in developing countries can lead to adverse human health effects and environmental pollution.

The origin of e-waste comes from a manufacturer of electrical and electronic equipment and then bought and used for households, businesses, and public sector. Each product has a different life-time and will be e-waste after the end of life-time. Nowadays, e-waste management practices done by recycling, landfilled, incinerated or disposed of and traded both legal and illegal. Some in the developed countries such as EU and USA have developed a new approach of ewaste management called as "official take back system". This new approach also called as Extended Producer Responsibility. Description of e-waste management may be described in the figure below:

\footnotetext{
${ }^{2}$ Deepali Sinha Khetriwal, Philipp Kraeuchi, Rolf Widmer, 2007, Producer Responsibility for ewaste management: Key issues for considerations-Learning from the Swiss experience, Journal of Environmental Management, xx:1-13.
} 


\section{Figure 1. E-Waste Management Scheme}

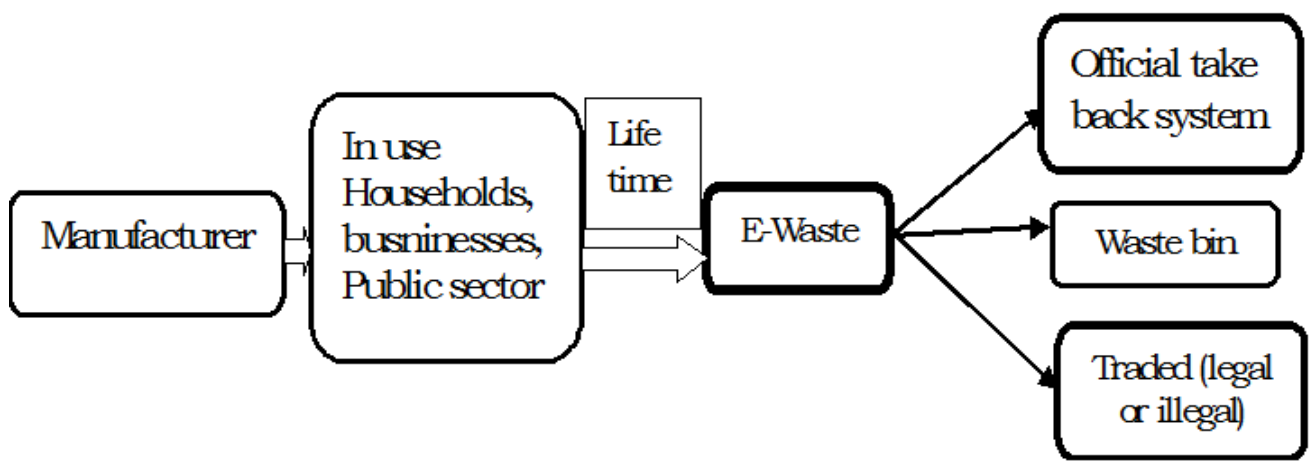

Increased consumption of electrical and electronic equipment due to its utilization in the day-to-day life of individuals has indirectly explained the increase in the generation of e-waste. Indonesia with population 250 million is a big consumers and good market for electrical and electronic equipment manufacturer. It is parallel with the increasing of e-waste in Indonesia. Unfortunately, there is no credible data represents amount of e-waste in Indonesia. Mostly, people don't know the menace of e-waste components to environment and human health if not disposed of carefully. Conversely, Many consumers do not immediately dispose of or recycle unused electronic since they think that the products still have value. People assumes that e-wastes still have economic value especially components containing gold, silver, iron, copper and alloy. Or e-waste may be reused or resold after doing repair of certain components.

While some naturally occurring substances are harmless in nature, their use in the manufacture of electronic equipment often results in compounds which are 
hazardous (e.g. chromium becomes chromium VI). The health effects of certain substances are summarized in Table $1 .^{3}$

Table 1. Health Effects of Certain Substances

\begin{tabular}{|c|c|c|}
\hline Source of e-wastes & Substance & Health effects \\
\hline $\begin{array}{ll}\text { PCB } & \text { (polychlorinated } \\
\text { biphenyls) } & \end{array}$ & $\begin{array}{l}\text { Condensers, } \\
\text { Transformers }\end{array}$ & $\begin{array}{l}\text { Cancer in animals, effects on the } \\
\text { immune system, reproductive } \\
\text { system, nervous system, } \\
\text { endocrine system and other health } \\
\text { effects. }\end{array}$ \\
\hline $\begin{array}{l}\text { Solder in printed circuit boards, } \\
\text { glass panels and gaskets in } \\
\text { computer monitors }\end{array}$ & Lead (PB) & $\begin{array}{l}\text { 1. Damage to central and } \\
\text { peripheral nervous systems, } \\
\text { blood systems and kidney } \\
\text { damage } \\
\text { 2. Affects brain development of } \\
\text { children }\end{array}$ \\
\hline $\begin{array}{l}\text { Chip resistors and } \\
\text { semiconductors }\end{array}$ & Cadmium (CD) & $\begin{array}{l}\text { 1. Toxic irreversible effects on } \\
\text { human health } \\
\text { 2. Accumulates in kidney and } \\
\text { liver } \\
\text { 3. Causes neural damage } \\
\text { 4. Teratogenic }\end{array}$ \\
\hline $\begin{array}{l}\text { Relays and switches, printed } \\
\text { circuit boards }\end{array}$ & Mercury (hg) & $\begin{array}{l}\text { 1. Chronic damage to the brain } \\
\text { 2. Respiratory and skin disorders } \\
\text { due to bioaccumulation in } \\
\text { fishes }\end{array}$ \\
\hline $\begin{array}{l}\text { Corrosion protection of } \\
\text { untreated and galvanized steel }\end{array}$ & $\begin{array}{l}\text { Hexavalent } \\
\text { chromium }(\mathrm{Cr}) \mathrm{VI}\end{array}$ & $\begin{array}{l}\text { 1. Asthmatic bronchitis } \\
\text { 2. DNA damage }\end{array}$ \\
\hline
\end{tabular}

\footnotetext{
${ }^{3}$ L.Nageswara Rao, 2014, Environmental Impact of Uncontrolled Disposal of E-Wastes, International Journal of ChemTech Research, Vol 6 No.2, pp 1343-1353, April-June 2014, page 1345 .
} 


\begin{tabular}{|c|c|c|}
\hline $\begin{array}{l}\text { plates, decorator or harder for } \\
\text { steel housing }\end{array}$ & & \\
\hline Cabling and computer housing & $\begin{array}{l}\text { Plastics including } \\
\text { PVC }\end{array}$ & $\begin{array}{l}\text { Burning produces dioxin. It } \\
\text { causes } \\
\text { 1. Reproductive } \\
\text { developmental problems } \\
\text { 2. Immune system damage } \\
\text { 3. Interfere with regulatory } \\
\text { hormones }\end{array}$ \\
\hline $\begin{array}{l}\text { Plastic housing of electronic } \\
\text { equipments and circuit boards }\end{array}$ & $\begin{array}{l}\text { Brominated flame } \\
\text { retardants (BFR) }\end{array}$ & $\begin{array}{l}\text { Disrupts endocrine system } \\
\text { functions }\end{array}$ \\
\hline Front panel of CRTs & Barium $(\mathrm{Ba})$ & $\begin{array}{l}\text { Short-term exposure causes } \\
\text { 1. Muscle weakness } \\
\text { 2. Damage to heart, liver and } \\
\text { spleen }\end{array}$ \\
\hline Motherboard & Beryllium & $\begin{array}{l}\text { 1. Carcinogenic (lung cancer) } \\
\text { 2. Inhalation of fumes and dust } \\
\text { causes chronic beryllium } \\
\text { disease or berylliosis } \\
\text { 3. Skin diseases such as warts }\end{array}$ \\
\hline
\end{tabular}

Source: L.Nageswara Rao, 2014 and http://ewasteguide.info/hazardous-substances

A study on the issues of electronic waste in the developing countries showed that China, Cambodia, India, Indonesia, Pakistan and Thailand and African states such as Nigeria, have received electronic waste from developed countries although each has specific e-waste problems. The african states tend to reuse the discarded products but Asia states tend to dismantle e-waste and taking economically valued certain components by using unsafe method for health. ${ }^{4}$

\footnotetext{
${ }^{4}$ Peeranat Kiddee, Ravi Naidu, Ming H.Wong, 2013, Waste Management, Journal Elseveir, journal homepage:www.elseveir.com/locate/wasman, page 1238.
} 
Social problems and human health have been a common concern for developing countries such as China, India and Asia countries. They have already amended their regulations adjusted to management and e-waste import. In addition, electrical and electronic equipment manufacturers both in developed countries and in developing countries have made every endeavor to handle e-waste by new technology. ${ }^{5}$

Referring to Law No. 18 of 2008 on Waste Management, e-waste is categorized as specific waste that means a waste needs a specific management because of its nature, concentrate and/or volume (Article 1 point 2). Under Law No. 32 of 2009 on Environmental Protection and Management, e-waste includes hazardous waste (Limbah Bahan Berbahaya dan Beracun) as stipulated in Article 1 point 22. The Government of Indonesia prohibits e-waste import and obliges manufacturer to attach label or mark related to mitigating and handling waste on packaging and/or products (Article 14 Law No. 18 of 2008). Manufacturers also have obligation to manage packaging and/or products which is not or hard disentangled naturally (Article 15). The both laws were based on the cradle to grave concept where the generation, storage, transportation, treatment and disposal of wastes are regulated. Then, the laws were strengthened by Government Regulation No. 101 of 2014 on Hazardous Wastes Management.

The existing laws haven't guaranteed the eradication of illegal e-waste trade in Indonesia like what happened in Batam albeit the Basel Convention prevails. No official data available for used electronic appliances and e-waste importation and ewaste smuggling in Batam. Regarding e-waste trading, FX Joko Priyono in the research report of 2012 concerning the implementation of Basel Convention and General Agreement on Tariff and Trade (GATT) in restricting e-waste showed the both international agreements have not given positive contribution to crack down ewaste trade. ${ }^{6}$ This case indicates that control cross-border of waste is a difficult

\footnotetext{
5 Widmer, R.Lombard, R, 2005, E-Waste Assesment in South Africa a Case Study of the Gauteng Province, EMPA, page 1-62.

${ }^{6}$ FX Joko Priyono, 2012, Masalah Pembatasan Ekspor Sampah Elektronik: Perspektif Konvensi Basel dan GATT/WTO, Jurnal Masalah-Masalah Hukum, Jilid 41 No. 4.
} 
tasks and requires strong coordination among institutions. Modus of transboundary movement of e-waste is subjected to raw material, reconditioning/re-use, charity, and disposal. We know that Batam has some gates for entry both officially and unofficially. Close distance between Batam and Singapore affects the e-waste smuggling and it is lack of control by central government.

In this paper, law enforcement is understood as: ... any system by which some members of society act in an organized manner to enforce the law by discovering, deterring, rehabilitating, or punishing people who violate the rules and norms governing that society. The organization meant in the definition is the police in the prevention and punishment of e-waste smuggling crimes in Batam.

\section{Research Method}

This study was conducted in Batam to know deeply e-waste smuggling practices. It began by looking for e-waste smuggling case from key informants who know the smuggling practices. The founded key informants was then interviewed by Focus Group Discussion (FGD). The FGD was done for two days dated 10-11 August 2016. The participants were importer, army (TNI), user, intermediator, distributor. The discussion was based on the main issues regard with the entry of ewaste in Batam. Based on it, this research is classified as qualitative research.

\section{Results and Discussion}

As we know that e-waste is a part of hazardous waste. Transboundary movement of e-waste into Indonesia is inconsistent the Government regulations as provided in Law No. 18 of 2009 on Waste Management, Law No. 32 of 2009 on Environmental Protection and Management, Government Regulation No. 101 of 2014 on Hazardous and Toxic Waste Management, Trade Minister Regulation No. 48/M-DAG/PER/7/2015 on General Provisions of Import Products.

Article 2 of the Trade Minister Regulation stipulates that the imported products must be a new one. In special circumstances, Minister may stipulates the 
used products import as far as inconsistent with law; minister authority; and/or proposal or technical consideration from another government institutions. Referring to it, the used products including wastes are basically prohibited for import except any specific regulation.

In case of waste, trade ministry distinguishes import regulation as follows: 1) Industrial and Trade Minister Decree No. 0520/MPP/Kep/8/2003 on Hazardous Wastes Import Ban and 2) restriction of non-hazardous waste based on Trade Minister Regulation No. 31/M-DAG/PER/5/2016.

The Government of Indonesia has already ratified the Basel Convention. This measure reflects that Indonesia has a political will to protect environment and human health. The lack of hazardous waste facilities is a rational matter to strengthen e-waste import ban in Indonesia by issuing Government Regulation No. 101 of 2014 on Hazardous and Toxic Waste Management. Article 175 stipulates that "any person is prohibited for hazardous and toxic waste dumping into environmental media without authorization.

\section{A. E-Waste Trade}

The meaning of e-waste trade here is illegal e-waste trade due to e-waste import ban in Indonesia. E-waste trade practices are normally integrated either in hazardous waste or in separate waste.

E-waste trade may happen anywhere both in the world and Indonesia. In 2012, document adulteration occurred in the Port Tanjung Priok when the Custom suspected the arrival 113 containers and not consistent with the document bill of lading. The fact showed that it contained e-wastes such as PCB (Print Circuit Board), asphalt, chemicals packaging, and garbage. This infringement is certainly inconsistent with the provisions of non-hazardous waste as provided in Law No 32 of 2009 on Environmental protection and Management, Law No. 18 of 2008 on 
Waste Management and the Trade Minister Regulation No. 39 of 2009. ${ }^{7}$ This case also happened in the same year at the Tanjung Perak Surabaya where hazardous wastes founded in a container which contain such as used tires, batteries, tube, electronic cut, and sand contained cables.

Nowadays, no case for the both capital cities because the Regional Governments are seriously to uphold the law and have good waste management. Conversely, it is not parallel with Batam city. Many e-wastes are available in certain market and no law enforcement. The e-wastes may comes from either beyond Batam or domestic industries.

Batam is a city in the Riau Islands Province of Indonesia. The city of Batam consists of several islands, with Batam Island becoming the core urban area. Both Galang Island and Rempang Island are connected to Batam Island by short bridges, collectively called Barelang. These two islands maintain their rural character, as does nearby Bulan Island. Batam is an industrial boomtown, an emerging transport hub, and part of a free trade zone the Indonesia-Malaysia-Singapore Growth Triangle, located $20 \mathrm{~km} \mathrm{(12} \mathrm{mi)} \mathrm{off} \mathrm{Singapore's} \mathrm{south} \mathrm{coast.} \mathrm{The} \mathrm{Batam}$ municipality has a population of $1,162,352$ (prediction in 2015). It is the closest part of Indonesia to Singapore, at a minimum land distance of $5.8 \mathrm{~km}$. According to the 2010 national Census, Batam is the fastest-growing municipality in Indonesia, with a population growth rate of $11 \%$ per year. ${ }^{8}$ Batam City (Kotamadya Batam) is divided into 12 districts (kecamatan) - which include several adjacent islands such as Bulan, Rempang, and Galang, as well as Batam Island itself. The whole municipality is thus often known by the abbreviation of Barelang.

Batam as industry city has many problems related to the environment protection. Impacts of industries activities has affected ecosystem matters and changed lifestyle of people. People income increases and influences the increase of

\footnotetext{
${ }^{7}$ Deputi IV Minister of Environment and Forestry for Hazardous and Toxic Waste Management, Januari 2012. Accessed at http://www.menlh.go.id/sidak-b3/

${ }^{8}$ Batam Statistic Body, 2015, Batam in Number.
} 
consumption demands. One of them is electrical and electronic equipment. The fulfillment of electronic equipment demand may be imported from Singapore, Malaysia, Thailand and Vietnam and from domestic Manufacturers. The problem arises when the lifetime of electrical and electronic equipment ends up and then be e-waste.

For certain people, e-waste still has economic value and may be reused, recycled and dismantled for taking its components. They don't care about the menace of e-waste. Therefore, they even buy e-waste from Singapore to be used and resold in Indonesia. That's why Batam is famous with the cheapest secondhand electronic products.

In some places both in the certain road and in the certain market, the used electrical products was traded clearly. The research results also showed that the second-hand electronic products were from Singapore. The e-wastes are refrigerator, TV / LCD, computer/laptop, fan and handphone. This practices are not covered by the police and no law enforcement. To uncover such illegal e-waste trade practices, the research team held a Focus Group Discussion (FGD) in Batam. The participants encompasses key informants such as army (TNI), trader, user, and intermediator.

The study result showed that most of e-waste comes from Singapore. This e-waste was imported without container but directly transported by ship after paying the e-waste products in Singapore. Generally speaking, the ships are owned by a person and also as importer and seller to do distribution to retailer. The ship journey from Singapore to Batam was backed up by one army (TNI) or more and some civilians. The ship did not passed the official port or custom but directly went into unofficial place called as "pelabuhan rakyat" or "jalan tikus". For example, Tanjung Senkuang, Batu Ampar, Batam. In this area, Haji Toyyib is regarded as the boss and the owner of PT.Octavia Mandiri.

All e-wastes are then sorted and separated. If the some e-wastes still work well, the retailer will take them and sold at certain market such as Pasar Jodoh, 
Tanjung Senkuang, Aviari and My Mart. We may see some gadget dan electronic waste from Singapore offered cheaper than other and also available at Tanjung Senkuang Market located closer with shipyard Batu Ampar. Some e-wastes consists of fan, refrigerator, AC, TV and watch. It also happen at Aviari Market and My Mart Batam Center (used computer dan laptop).

Field research also found a few players or subjects of e-waste importer but the leading player was Haji Toyyib who has territory at Tanjung Senkuang as a place of shipyard. Special for used handphone is usually brought by hand baggage not more than 10 (ten). In September 2016, smuggling of handphone was cracked down by Directorate of Maritime Police of Polda Riau. The amount of handphone smuggling are more less 13.114 and done from Batam Water, Kepulauan Riau by using false document. ${ }^{9}$

The essence of the above cases are the differences of handling big and small smuggling. Police is successful to eradicate big smuggling but not for small smuggling. People responses as if the police ignores the smuggling practices. This image becomes more complex because people perception regards e-waste smuggling as a business and income source. This figure is an illegal e-waste trade scheme in Batam:

\footnotetext{
${ }^{9}$ Data Polda Kepulauan Riau, 2016.
} 
Figure 2. illegal e-waste trade scheme in Batam

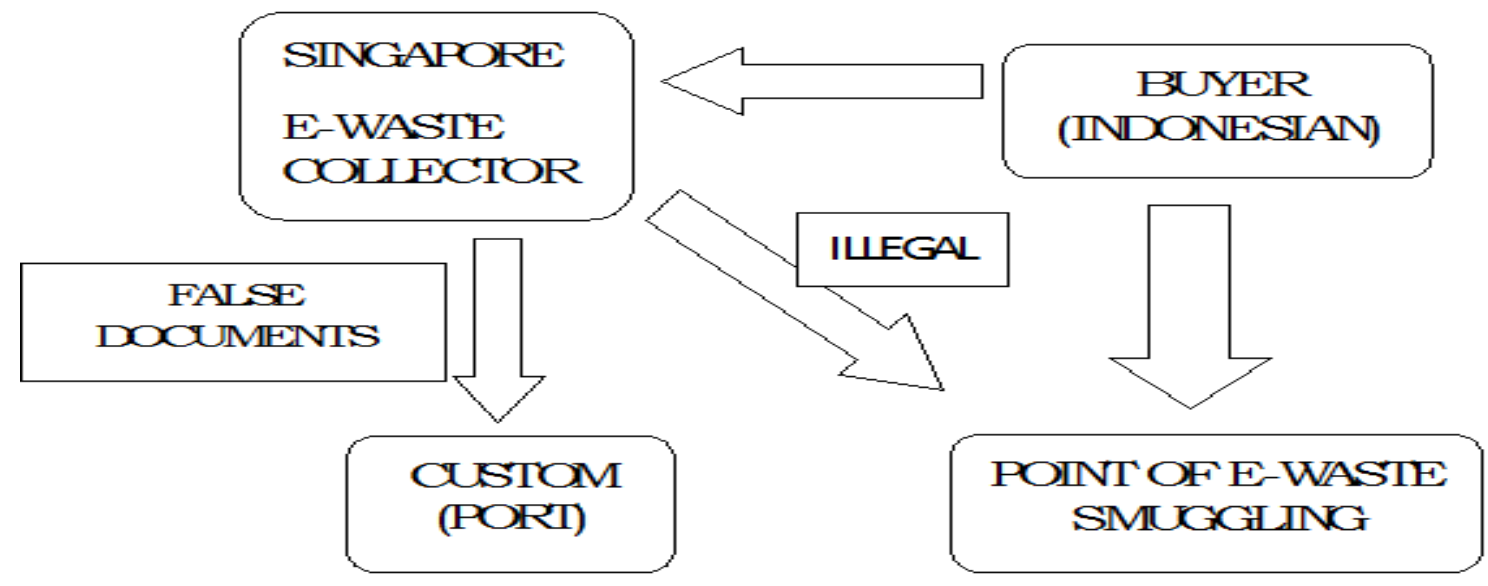

Illegal Trade of e-waste will jeopardize environment and human health. Therefore, efforts of eradicating the practices must be supported not only the Government but also the people awareness. The role of government including its agencies is very important to force the prevailing laws in connection with environmental protection and management. Manufacturers as producers of electrical and electronic equipment have obligation to manage e-waste. Hazardous and toxic waste management covers collection, transportation, utilization, management and accumulation activities. The hazardous and toxic waste management activities must obtain licenses from the Ministry of Environment (MoE) and every stage of B3 waste management activities must be reported to the Ministry of Environment. It must also be reported to Environment and Forestry Ministry and Regional Environmental Impact Control Body or called as "Badan Pengendalian Dampak Lingkungan Daerah" (BAPEDALDA).

As provided in Article 59 paragraph (1) Law N0. 32 of 2009 on Environmental Protection and Management and Article 3 paragraph (1) Government Regulation No. 101 of 2014 on Hazardous and Toxic Waste Management: "any person who produces hazardous and toxic waste has obligation 
to manage the waste. They may have third party to do waste management If they have no capacity or technology. Breaking the rules will be deemed offense.

Government Regulation No. 101 of 2014 has changed significantly over Government Regulation No. 18 and 85 year 1999 in which e-waste management should be integrated in order to avoid injury for human, animal, and plant health and environment.

E-Waste producers has responsibility commencing from the time of producing until annihilation (from cradle to grave) by doing internally management properly and convincing third party as waste management provider about competence and subject to regulation. Government Regulation No. 101 of 2014 stipulates that sources of hazardous and toxic wastes consists of specific source (general and specific), not specific, and hazardous waste expired, spill off, specification and used packaging of hazardous waste. The menace of hazardous waste is divided into two group, they are danger 1 and danger 2. It means that hazardous waste will begin from hazardous waste management, identification, decrease, storage, management by third party, emergency system, dumping and administration sanction.

In the lawsuit, claim of Hazardous waste includes formal claim. It means that a person or company may be subject to civil liability and offense due to inconsistency of management method with the prevailing law. Based on it, it is unnecessary to prove his actions for polluting environment.

For electronic waste produced by the domestic industries, the government should not merely prohibit the collector of electronic waste but also gave an understanding of the knowledge on how to do environmentally sound e-waste recycling. This measure has been done by the government of Bangalore City India by doing dissemination to people on how to recycle electronic waste. The dissemination consists of three stages: ${ }^{10}$

10 S.Manasi, Bibhu Prasad Nayak, N.Latha, 2011, Eco-threats of E-Waste, A Case Study of Bangalore City, Lambert Academic Publishing, page 45. 
a. Dismantling and separation: the collected e-waste was dismantled and separated into reused and recycled components. The reused component was sold to the different market while the recycled components was dismantled manually and then separated and sent to recycled products.

b. Recycling: components of the different computers was assembled and then be a new computer including monitor.

c. Extraction: after recycling, dismantling and separation, some materials which contain metal inside motherboards, handphone, processor, scanning machine such as gold, silver, nickel and platinum, sold or created for ornament.

\section{B. The Law Enforcement Distortion}

The main problems of e-waste trade in Indonesia are naturally on legal structure and legal culture of society. The prevailing laws have been sufficient to cover environmental crime. Three elements of legal system becomes integrated and may not be separated as Lawrence M.Friedman opinion. ${ }^{11}$

From the aspect of the legal structure, are still deficiencies regarding the integrity and the mentality of law enforcer. The legal structure includes institutions supporting the substance of the law, namely the police, customs, prosecutors and the judiciary. Police and Customs is the first institution and directly deal with the practice.

Based on the research results through the document inquiry and field studies including interviews founded the gap between what has been regulated in legislation, namely Law No. 32 of 2009 and Government Regulation No. 101 of 2014 with the reality and the legal facts in Batam. The existence of e-waste trade in Indonesia has proved the weakness of law enforcement. Its weakness lies not in the law, but lies in the role holder, namely the police, customs, prosecutors, courts, and

\footnotetext{
${ }^{11}$ Lawrence M. Friedman, 1984, American Law An Introduction, W.W.Norton \& Company, Inc 500 fifth Avenue, New York, page 5-6.
} 
lawyers. As stated by Satjipto Rahardjo that achievement and performance of law will be largely determined by men who run it. What is said and promised by the law, it will eventually become a reality through the hands of these people. When viewed from that perspective, it is relevant to talk about the various factors that influence on law enforcement. In fact, the law enforcement process culminated in the executing by law enforcement officials.

In the case of electronic waste trade, particularly in the city of Batam, law enforcement is very weak. Law enforcement agencies (police) seemed to not know or ignore what happened in the city of Batam. The influx of electronic waste through Tanjung Senkuang was not cracked down by legal apparatus. Even various electronic waste can be seen clearly in the certain markets such as Pasar Jodoh, Pasar Aviari, Pasar Tanjung Sengkuang, and My Mart.

From the aspect of legal culture, public perception of the electronic waste, as well as ignorance of the danger and its impact on the environment and human health, becomes a major factor for not complying the law. The economic values of electronic waste causes no effectivity of the law. It becomes more complex by the involvement of law enforcement officers in the circulation of electronic waste in Batam.

Interviews and $\mathrm{FGD}^{12}$ report showed that the problem of trafficking or influx of imported electronic waste in Batam is the result of collaboration or collusion between law enforcement officers with the importers and even the backing of the military component proves that law enforcement has become more complex. These actors will never realize that due to non-performance of law enforcement is not only extremely harmful to humans and other creatures but also very harmful to the earth. The recognition of one of the soldiers that the act was done because of economic necessity and opportunities indicates that law enforcement does not work well due to human factor.

${ }^{12}$ FGD was held on August 102016.

Diponegoro Law Review, April 2017, Volume 02, Number 01 
Law enforcement is a process that involves a lot of things. In principle, the law enforcement process still refers to the basic values in the law, such as justice (gerechtigheit), legal certainty (rechtssicherheit), and benefits of the law (zweckmassigkeit), the three elements that must be met in the process of law enforcement as well as a primary goal of law enforcement. The basic values are protection of the environment or ecosystem, protection of human health and other creatures. Thus, the basic values that ideally should have to be the main pillar in law enforcement of the ban of e-waste import as stipulated in Law No. 32 Year 2009 and Government Regulation No. 101 of 2014.

Law enforcement matter is also burdened with the bad perception of people regarding the effect of e-waste to environment and human health. People will never ask about the risk as far as the e-waste still works well. Economic values still becomes priority than others. They don't care about the menace of e-waste including the risk. E-waste users are a middle-class society.

Inflows of used computer and TV are driven mainly by the market needs of using e-waste than recycling. For example, a study conducted by Yoshida and Terazono on exporting TV second hand from Japan to the Philippines, the study results showed that $30 \%$ of TV which is imported directly sold on arrival in port, while the rest is done repair (repair) and the process is updated before being sold for reuse ( reuse). ${ }^{13}$

Electronic waste is not just from import, but also from the domestic industry. Even so, the public perceives the weakness of law enforcement. Law is blunt at the top but sharply at down. Law enforcement is a key element in protecting the environment or ecosystem. Collusion among law apparatus will make the collapse of the law itself.

13 A.Yoshida and A .Terazono, 2010, Reuse of secondhand TVs exported from Japan to the Philipines, Waste Management, 30, 1063-1072. lihat Pula Klaus Hieronymi, Ramzy Kahhat and Eric Williams, 2013, E-Waste Management from waste to resource, edited by Klaus Hieronymi, Ramzy Kahhat amd Eric Williams 
One of the interesting cases in Batam regarding the implementation of Law No. 32 of 2009 on the Protection and Environmental Management is the alleged environmental criminal offenses done by PT.Maruwa, a Foreign Investment Company which is located in Star Industrial Complex II Tanjung Uncang, Batam. It happened on October 9, 2005, when the company did loading six big bag containing e-waste over car "lori" owned by PT. Great central Himalaya to be transported to PT Sentral Agung Himalaya without license and Supervision Sheet of BAPEDAL Batam. Article that alleged against PT Maruwa Indonesia is Article 102 and Article 59 paragraph (4) Law No. 32 of 2009. Article 59 (4): "Hazardous and Toxic Waste management must obtain a license from the Minister, the Governor, or regent/mayor in accordance with its authority". Article 102: "Anyone who generates hazardous and toxic waste and does not perform management as referred to in Article 59, shall be punished with imprisonment of at least one (1) year and a maximum of three (3) years and a fine of at least Rp1,000,000,000.00 (one billion rupiah) and at most Rp3.000.000.000,00 (three billion rupiah) ".

The case was eventually stopped and not included environmental crimes on the grounds that electronic waste in the form of Flexible Printed Circuit of PT. Maruwa Indonesia loaded at the car Lori PT. Great central Himalayas are not included in the list of prohibited Hazardous waste as set forth in the Appendix of Government Regulation No. 101 of 2014 on the management of hazardous and toxic. ${ }^{14}$ The Appendix stipulates that waste for both the assembly of electronic components or electronic equipment as follows:

Table 6. Waste of the assembly of electronic components or electronic equipment

\begin{tabular}{|l|l|c|}
\hline Waste code & Waste description & Risk category \\
\hline A328-4 & Caustic strapping (photoresist) & 1 \\
\hline
\end{tabular}

\footnotetext{
${ }^{14}$ Interview with KOMPOL Idris POLDA Kepulauan Riau, dated August 122016.
} 
Law Enforcement Of Electrical And Electronic Waste Smuggling In Batam, Indonesia

\begin{tabular}{|l|l|c|}
\hline A328-5 & Sludge assembly production & 1 \\
\hline B328-1 & Cathode Ray Tube (CRT) & 2 \\
\hline B328-2 & Coated glass & 2 \\
\hline B328-3 & Residue solder and flux & 2 \\
\hline B328-4 & Printed circuit board (PCB) & 2 \\
\hline B328-5 & Metal cable waste and insulant & 2 \\
\hline B328-6 & Sludge from IPAL & 2 \\
\hline
\end{tabular}

Flexible Printed Circuit Waste as the result of the electronic component assembly by PT. Maruwa Indonesia is not included in the types of waste as set out in the annex. The term electronic waste description set forth in the attachment is Printed Circuit Board (PCB). It means that the annex does not mention flexible printed circuit. Although the nomenclature does not exist in the Government Regulation No. 101 of 2014, but it does not mean the action can't be covered as offense. The way of thinking like this will not be able to cover the crime. Whereas components of Flexible Printed Circuit and printed circuit (B328-4) may damage the environment and human health. It is so simple to say that Flexible Printed Circuit Waste can not be reached by law. Legal facts showed clearly regarding the existence of action to dispose of e-waste in the environment media.

Here are the conclusions of the Riau Islands Police in handling case of PT Maruwa Indonesia:

1. Waste generated by PT Maruwa Indonesia, as follows :

a. Chemicals Hazardous and Toxic Waste (IPA, Solder Paste, Solder Ball);

b. Used Oil Waste and Grease;

c. Hazardous waste packaging (cans, bottles, tubes);

d. Towel waste and used gloves and cotton stick of contaminated hazardous waste material ;

e. Waste FPC (Flexible Printed Circuit) 
2. The Facts as follows :

a. PT Maruwa Indonesia is a foreign investment engaged in the electronic components industry flexible printed circuit, established in 1998 and located in Star Industrial II Block C No. 31-31 Jl.Brigjend Katamso Uncang Tanjung Batam;

b. PT Maruwa Indonesia has have dumping area for hazardous waste and licensed;

c. Founded loading 6 big Bag of e-waste over the car;

d. Time period of hinder ordonantie ends up;

e. Never report Hazardous waste management quarterly to BAPEDAL Batam;

f. FPC waste is not listed in the annex of Government Regulation No. 101 of 2014;

g. Based on the letter of BAPEDAL and coordination Napedal and the Ministry of Environment on 19 November 2015, the FPC waste not included hazardous and toxic waste

3. Legal Basis

a. Article 1 point 32 of Law No. 32 of 2009 on the Protection and Environmental Management: hazardous and toxic waste management covers vigorous reduction, collection, storage, transport, use, processing and or hoarding;

b. Article 59 paragraph 1 of Law No. 32 of 2009 on the Protection and Environmental Management: any person who generates hazardous and toxic waste must carry out waste management;

c. Article 59 paragraph 4 of Law No. 32 of 2009 on the Protection and Environmental Management: Management of hazardous and toxic waste must get license from the minister, governor or regent/mayor in accordance with its authority; 
d. Article 102 of Law No. 32 of 2009 on the Protection and Environmental Management: any person who commits the management of hazardous waste without a permit as stipulated in Article 59 paragraph 4 will be sentenced minimum 1-year maximum 3 years and a fine of at least 1 billion, a maximum of 3 billion;

The release of PT Maruwa Indonesia from lawsuits is unacceptable in terms of legal reasoning. The facts of disposal of electronic waste in the form of flexible printed circuit by PT Maruwa Indonesia is so clear and breaking the law. Lack of understanding on legal knowledge which treat the same as law and laws will make ineffectiveness of law enforcement.

\section{Conclusion}

E-waste trade practices are inconsistent with Law No. 32 of 2009 and Government Regulation No. 101 of 2014. Violation of the law has happened due to the weakness of legal structure such as police and custom. The ignorance of entering e-waste from Singapore to Batam reflects a difficulty to uphold the law. Ewaste trade practices in Batam was backed up by army (TNI) and Police. Smuggling practices is more complex due to lack of the awareness of people regarding menace of e-waste for health. In terms of PT Maruwa Indonesia case, it reflects lack of legal knowledge of the police in implementing the rules. e-waste smuggling will never end up as long as no mentality and morality improvement of the regional government bureaucrat and the police.

Legal culture of the people of Batam causes the ineffectiveness of law enforcement to uphold e-waste trade smuggling. They regard e-waste still have economic value. Therefore, they don't care about the menace of e-waste to the environment and human health. The government should develop the people for managing e-waste properly while prohibiting e-waste import. Model of the 
government Bangalore city of India may becomes a model for the regional government of Batam.

\section{References}

A.Yoshida and A.Terazono, 2010, Reuse of secondhand TVs exported from Japan to the Philipines, Waste Management, 30, 1063-1072.

B Klaus Hieronymi, Ramzy Kahhat, and Eric Williams, 2013, E-Waste Management from waste to resource, edited by Klaus Hieronymi, Ramzy Kahhat, and Eric Williams

Batam Statistic Body, 2015, Batam in Number.

Data Polda Kepulauan Riau, 2016.

Deputy IV Minister of Environment and Forestry for Hazardous and Toxic Waste Management, January 2012. Accessed at http://www.menlh.go.id/sidak-b3/ Deepali Sinha Khetriwal, Philipp Kraeuchi, Rolf Widmer, 2007, Producer Responsibility for e-waste management: Key issues for considerationsLearning from the Swiss experience, Journal of Environmental Management, $\mathrm{xx}: 1-13$.

Eric Williams, 2013, E-Waste Management from waste to resource, edited by Klaus Hieronymi, Ramzy Kahhat and Eric Williams

FX Joko Priyono, 2012, Masalah Pembatasan Ekspor Sampah Elektronik: Perspektif Konvensi Basel dan GATT/WTO, Jurnal Masalah-Masalah Hukum, Jilid 41 No. 4.

L.Nageswara Rao, 2014, Environmental Impact of Uncontrolled Disposal of EWastes, International Journal of ChemTech Research, Vol 6 No.2, pp 13431353, April-June 2014.

S.Manasi, Bibhu Prasad Nayak, N.Latha, 2011, Eco-threats of E-Waste, A Case Study of Bangalore City, Lambert Academic Publishing.

Step (Solving the E-waste Problem), 2014. One Global Definition of E-Waste, United Nations University, 3 June 2014.

Widmer, R.Lombard, R, 2005, E-Waste Assesment in South Africa a Case Study of the Gauteng Province, EMPA.

\section{Regulation}

Law No. 18 of 2008 on Waste Management

Law No. 32 of 2009 on Environmental Protection and Management

Government Regulation No. 101 of 2014 on Hazardous and Toxic Waste Management 